\title{
Analysis on the change of runoff curve number influence to surface flow debit using ALOS AVNIR-2 data imagery
}

\author{
(Analisis perubahan jumlah kurva limpasan terhadap debit aliran permukaan \\ menggunakan citra data ALOS AVNIR-2)
}

\author{
Wenang Anurogo*1, Kartika Pratiwi**, Muhammad Zainuddin Lubis**, Mir'atul Khusna \\ Mufida*, Luthfiya Ratna Sari*, Siti Noor Chayati* \\ * Politeknik Negeri Batam, Jl. Ahmad Yani Batam Kota, Batam Kepulauan Riau, 29461, Indonesia \\ ** Universitas Gadjah Mada, Jl. Teknika Utara, Pogung, Sinduadi, Mlati, Sleman, Yogyakarta, 55284, \\ Indonesia \\ ${ }^{1}$ Corresponding author, Surel: wenang@polibatam.ac.id
}

Paper received: 19-03-2021; revised: 27-07-2021; accepted: 19-08-2021

\begin{abstract}
One part of the hydrologic cycle which has a major influence in increasing the amount of river flow discharge is surface runoff. The higher surface runoff discharge, causing the possibility of surface flooding, therefore required an empirical model that can calculate the amount of surface runoff so as to produce updated data and quickly change according to their needs. One of the empirical methods that can be used to calculate the amount of surface runoff is by using the curve number method. This research is done by utilizing remote sensing image, that is, ALOS AVNIR-2. Data extraction from ALOS imagery includes land cover information using multispectral classification analysis, slope inclination information through visual interpretation, and land use interpretation. The runoff that occurred in Banjarnegara Regency tends to be high, that is, 61.24 percent of the total area of the research area Large runoff with very high/extreme class spread on the form of hilly land to the old volcano complex at the study site. The runoff in the medium to low class only covers 3.56 percent of the total area and is distributed on the fluvial form with the flat-to-flat slopes. The result of analysis of runoff data is obtained from slope analysis and type of land use in the research location. Increasingly steep slope with little vegetation-land use, then the greater the runoff that occurs. Finally, the research result could be implemented into higher student class activity, especially in remote sensing classes, GIS, cloud computing, and big data analysis. By this process, the students will be improved their skills in analyzing imagery data as well as create new information derived from the remote sensing data.
\end{abstract}

Keywords: surface runoff; curve number; remote sensing; ALOS data imagery

\section{Introduction}

Surface runoff as part of the hydrological cycle is a component that greatly affects the size of river flow discharge. Surface run-off is part of the rainfall that enters the soil watersaturated so that the water goes out to the surface and flows across the surface to the lower place (Lian et al., 2020). The higher surface runoff discharge, causing the possibility of surface flooding, therefore required an empirical model that can calculate the amount of surface runoff so as to produce updated data and quickly change according to their needs. One of the empirical methods that can be used to calculate the amount of surface runoff is by using the curve number method (Anurogo et al., 2018). 
Jurnal Pendidikan Geografi:

Kajian, Teori, dan Praktek dalam Bidang Pendidikan dan Ilmu Geografi

27(1), 2022, 15-25

The curve number expresses the effect on soil, hydrological state, and previous water content, where the factors can be obtained from soil surveys, local studies, and land use maps (Ebrahimian et al., 2018; Lal et al., 2016). Some of the factors required in estimating curve numbers include meteorological properties such as volume and surface flow rate, and river basin factors. Curve number estimation requires an index representing the meteorological factor and the surface flow region. The possible index representing the meteorological factor is the volume of rainfall, where the volume of rainfall will affect the volume of surface flow formed. The index of flow area properties can be obtained from soil type information, land use, and closing hydrological conditions. The information obtained predicts the surface flow volume (Guswa et al., 2017; Sari et al., 2018).

Land use change is a transition from specific land use to other uses. The process of human land use from time to time continues to change along with the development of civilization and human needs. The higher the human need will be, the higher the need of the land (Anurogo et al., 2015; Sudira et al., 2017). Humans are increasingly making changes in land use towards nature, the greater level of damage that is generated (Lubis et al., 2018; Uwizeyimana et al., 2019). One of the negative impacts of human activity is the occurrence of floods and landslides. Floods and landslides occur due to increased surface flow discharge due to rain falling in the river area that is not absorbed but runs over into overland flow. The results to be achieved in this study is to obtain the level of satellite image quality and other remote sensing data to identify the amount of surface flow discharge in the Banjarnegara area.

\section{Methods}

The research area is located in Banjarnegara Regency, Central Java Province. The area of Banjarnegara is located between X: 320000 Y: 9210000 up to X: 380000 Y: 9160000 on Universal Transverse Mercator (UTM) projection with World Geodetic System (WGS) datum 1984 Zone 49 South equator. It is generally in a flat topography to mountainous domains of plantations and agriculture. The use of plantation land on hilly topography is often found due to social background, i.e., the need for food of local people, so that the management of plantation land keeps increasing along with the increase of population, while the land area is fixed. The background triggered the community to cultivate land with intercrops and plantations, although not in accordance with the land conditions for plantations, i.e. on land conditions on the topography of the slopes. Land use that is inconsistent with the existing land capacity is triggered by the population's need for food and the backdrop of profits generated economically through planting of plantation crops so that local people continue to manage the land on existing land conditions. The research location is shown in Figure 1.

This research is done by utilizing a remote sensing image that is ALOS AVNIR-2. Data extraction from ALOS imagery includes land cover information using multispectral classification analysis, slope inclination information through visual interpretation, and land use interpretation (Danoedoro, 2012). Soil and landform map analysis was performed to explain the soil texture, which aims to obtain curve number values. The accuracy of visual interpretation results is improved with field data obtained from field checks. Field checks included observation of field terrain characteristics, land cover/land use interpretation, slope checking, and soil sampling for texture analysis. The method used in this study is the curve number method, which is the estimation of surface flow curve number. Curve number estimation is obtained from the SCS model by combining digital land use change data with soil hydrological type digital data. The sum of curve number values is 0 to 100 , which is divided 
into ten classes with equal intervals (ten). SCS (Soil Conservation Service) is an index called Runoff Curve Number (CN) (Satheeshkumar et al., 2017; Tiwari et al., 2018). Runoff Curve Number is Surface Flow Curve Number which is influenced by soil type, hydrological state, and water content of research area (Zeng et al., 2017).

The US Soil Conservation Service (US-SCS, 1973) developed the Runoff Curve Number (CN) index or Surface Flow Curve Numbers. Curve number indices express the effect on soil, hydrological state, and previous water content (Anurogo et al., 2017; Singhai et al., 2019). These factors can be obtained through ground surveys, field checks, and land use maps. The value of the curve number to be obtained depends on each soil group resulting from integration of several factors, namely the use of soil, treatment, and hydrological conditions. The classification system developed by the Soil Conservation Service (SCS) groups the soils into four groups of land marked with the letters A, B, C, and D. The SCS soil groups can be obtained through soil properties, soil maps, and minimum infiltration rates. In this study, the SCS land group was obtained through land maps, where the land maps were able to provide detailed information on the properties of the soil required and provide information on the location of the land that became the object of the study. Determination of Curve Numbers from the SCS model is done by combining digital type hydrological data of soil with digital land use data. Obtaining the value of Curve Numbers (CN) should be done with the addition of variables with values based on Table 1 (Ahmad \& Verma, 2018; Savvidou et al., 2018).

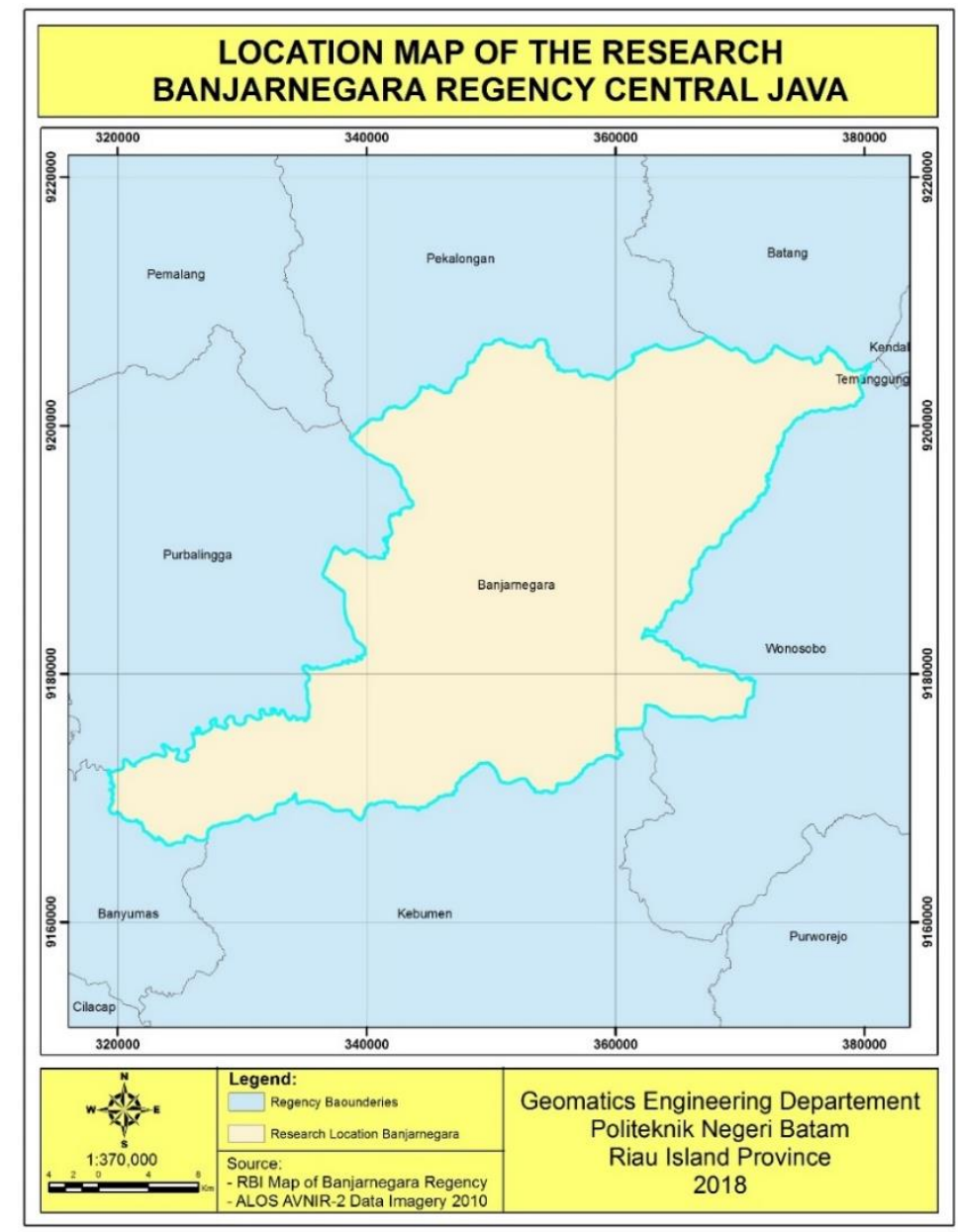

Figure 1. Location of the Research 
Jurnal Pendidikan Geografi:

Kajian, Teori, dan Praktek dalam Bidang Pendidikan dan Ilmu Geografi

27(1), 2022, 15-25

Table 1. Surface Flow Curve Number of Several Types of Land Use

\begin{tabular}{|c|c|c|c|c|c|}
\hline \multirow{2}{*}{\multicolumn{2}{|c|}{ Use of soil/treatment/hydrological conditions }} & \multicolumn{4}{|c|}{ Soil Hydrology Group } \\
\hline & & A & $\mathrm{B}$ & $\mathrm{C}$ & $\mathrm{D}$ \\
\hline \multirow[t]{3}{*}{ Forest } & Good & 25 & 55 & 70 & 77 \\
\hline & Moderate & 36 & 60 & 73 & 79 \\
\hline & Damaged & 45 & 66 & 77 & 83 \\
\hline \multirow[t]{3}{*}{ Grass } & Good $(>75 \%)$ & 39 & 61 & 74 & 80 \\
\hline & Moderate (50-75\%) & 49 & 69 & 79 & 84 \\
\hline & Damaged $(<50 \%)$ & 68 & 79 & 86 & 89 \\
\hline \multicolumn{2}{|c|}{ Agricultural land with conservation treatment } & 62 & 71 & 78 & 81 \\
\hline \multicolumn{2}{|c|}{ Agricultural land without conservation treatment } & 72 & 81 & 88 & 91 \\
\hline \multicolumn{2}{|c|}{ Settlements and farming } & 59 & 74 & 82 & 86 \\
\hline \multicolumn{2}{|c|}{ Settlement and non-farming } & 77 & 85 & 90 & 92 \\
\hline \multicolumn{2}{|c|}{ Ground / open land } & 77 & 86 & 91 & 94 \\
\hline
\end{tabular}

Table 2. Percentage of Land Cover Classification

\begin{tabular}{lll}
\hline No. & Slope Class (\%) & Information \\
\hline 1 & $<8$ & Flat \\
2 & $8-15$ & Ramps / choppy \\
3 & $16-25$ & Slightly tilted / wavy \\
4 & $26-40$ & Tilted / Hilly \\
5 & $>40$ & Steep \\
\hline
\end{tabular}

Tabel 3. Classification of Land Slope Class

\begin{tabular}{lll}
\hline No. & Percentage of land cover classification $(\%)$ & Class \\
\hline 1 & $>80$ & Very good \\
2 & $61-80$ & Good \\
3 & $41-60$ & Moderate \\
4 & $21-40$ & Bad \\
5 & $<20$ & Very Bad \\
\hline
\end{tabular}

The soil properties associated with the four groups marked with letters A, B, C, and D were developed by SCS for the soil classification system, with the following divisions: a) Group A (Deep sand, aggregated dust), b) Group B (Sandy clay), c) Group C (Clay loam, shallow sandy clay, low grade organic soil, and high clay soils), and d) Group D (Substantially expanding soils if wet, wet clay, plastic, and certain saline soils). The result of land use information integrated with the information of the soil type group will produce the value of the curve number. Table The slope classification and land use used are shown in Table 2 and Table 3.

The Physical factors that effect are the condition of relief, slope, soil type, and land use. For example, in Merawu Formation, the process is the result of Marin's process of forming a precipitate with a thickness of $>500 \mathrm{~m}$ so that it can cause a large enough landslide potential. Physical factors of the slope and soil type will affect the size of the runoff, while the soil solum influences the development of critical land due to the size of the soil loss or erosion. ALOS AVNIR-2 imagery was applied to identify the potential flow rate in the known Banjarnegara district by using related parameters. 
Non-physical factors that trigger the magnitude of the surface flow caused by the factor of population growth and the origin of the income sector of the population mainly obtained from agricultural products. The population growth triggered the increasing population demand for land management, causing population pressure on land to convert land use from hardwoods/forests to mono-cultural crops. So, in a certain time, with the condition of the land area is fixed, the increased demand for agricultural land will increase, in this case, the change in land use that occurs is a change from conservation land into a mono-cultural plantation, the potato plantation. The change in land use resulted in a decrease in the ability of the soil to absorb water, resulting in an increased surface flow.

\section{Results and Discussion}

The Determination of surface runoff using numerical curve method using three parameters that influence. These parameters are land cover conditions, slope, and soil texture in the research area. Analysis of curve number and the value of soil hydrology curve number, land use classification is needed based on SCS (Soil Conservation Service) method. The SCS method is a method that assumes the state of the groundwater content in its mean form, the value obtained expresses the effect on soil, hydrological conditions, and previous moisture content. The land cover is extracted from ALOS image data using NDVI, each channel used is a red wave with a channel coverage width of between $0.61 \mu \mathrm{m}-0.69 \mu \mathrm{m}$ and near infrared waves with a channel coverage width of $0.79 \mu \mathrm{m}-0.89 \mu \mathrm{m}$. Interpretation of Land Use Based on SCS Methods in the research area is shown in Table 4.

Table 4. Interpretation of Land Use based on SCS Method

\begin{tabular}{llll}
\hline No. & Information & Area (Ha) & Percentage (\%) \\
& & & \\
\hline 1 & Forest in good condition & 2934.85 & 2.67 \\
2 & Forest in moderate condition & 246.64 & 0.22 \\
3 & Forests in bad condition & 68.01 & 0.06 \\
4 & Agriculture Conservation & 67232.63 & 60.39 \\
5 & Non-Agriculture Conservation & 19943.55 & 17.91 \\
6 & Non-Agricultural Settlements & 1679.49 & 1.59 \\
7 & Agricultural Settlements & 4756.99 & 4.27 \\
8 & Grass in good condition & 6507.63 & 5.85 \\
9 & Grass in moderate condition & 667.04 & 0.60 \\
10 & Open Land & 430.28 & 0.39 \\
11 & Lake / Reservoir & 485.59 & 0.44 \\
12 & Cloud cover & 5951.88 & 5.35 \\
13 & No Data & 3604.45 & 3.24 \\
\hline & Total & 111327.54 & 100 \\
\hline
\end{tabular}

The results of land cover classification using NDVI analysis resulted in five classes of land cover, which are distinguished by the density of vegetation cover on the surface of the earth, namely: the land cover that falls into the category of very good, good, medium, bad and very bad. The category is based on the percentage of vegetation density, where land cover with very poor category has a percentage of vegetation cover of less than $20 \%$, the bad category has a percentage of $21-40 \%$, the medium category has a percentage of $41-60 \%$, the good category has a percentage of $61-80 \%$ and very good category has a percentage of more than $80 \%$. The percentage of land cover is done using the density slice method. The density slice method is 
Jurnal Pendidikan Geografi:

Kajian, Teori, dan Praktek dalam Bidang Pendidikan dan Ilmu Geografi

27(1), 2022, 15-25

used to reclassify NDVI classification results that produce several separate classes. Process method of density slice shown in Figure 2.

The data analysis results show that there are several types of land use in Banjarnegara, namely the use of forest land, agriculture, settlement, grass, fallow/open land, and reservoir. In the land use type, SCS method is grouped again into a more detailed type of land use. The slope is the next parameter used to construct a surface runoff model using a curve number model. The slope is one of the most influential parameters in land identification through remote sensing image processing. Obtaining slope information in this study using topo to raster interpolation method, which is a method that takes into consideration the hydrological parameters in slope, such as a river. Data used in this research is contour and river line. Images of topo to raster interpolation with altitude information are shown in Figure 3.

Figure 3 shows the results of data analysis showing that the research area is dominated by flat slope classification up to the choppy slope, which is $71,514.43 \mathrm{Ha}$ or $62.45 \%$ of the total area, then sloping slopes up to the hilly area of $37,621.1$ ha or $32.86 \%$, and the steep slopes are only $1,769.05 \mathrm{Ha}$ or $1.54 \%$. Slope data strongly correlates to the potential for erosion in a region. But slope information alone is not enough to make the decision that steep slopes have high erosion. It should be included with soil information.

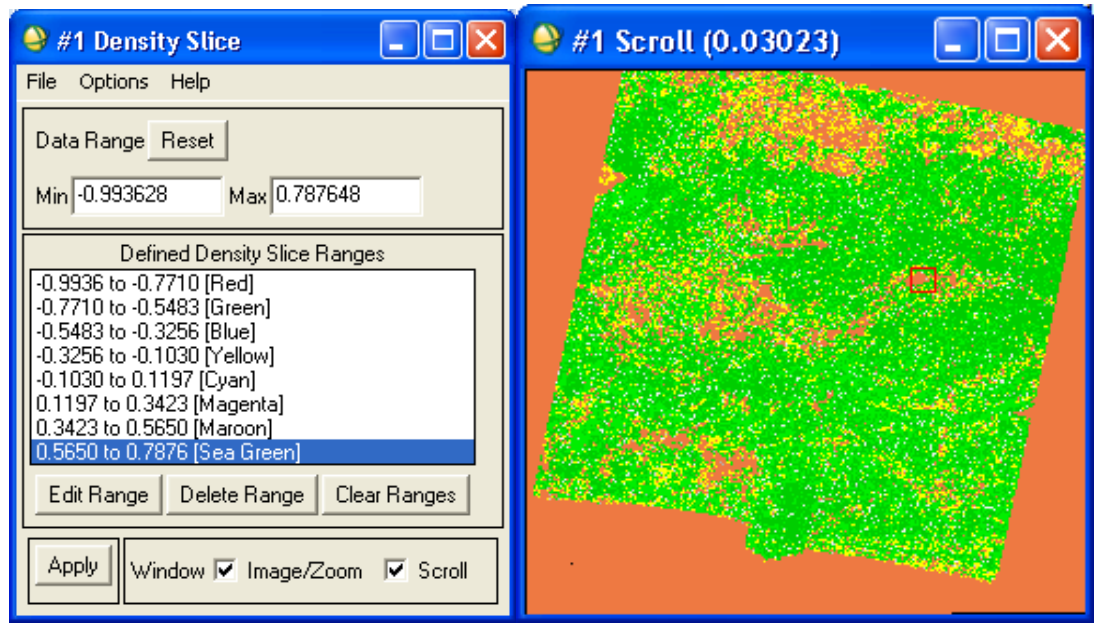

Figure 2. The Value and Number of Vegetation Density Classes based on NDVI Analysis

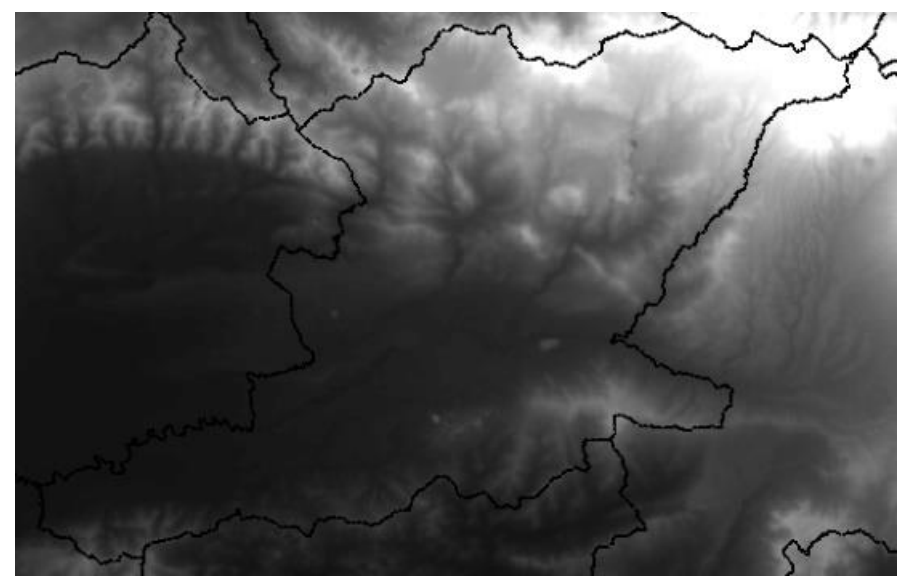

Figure 3. Topo to Raster Interpolation 
Jurnal Pendidikan Geografi:

Kajian, Teori, dan Praktek dalam Bidang Pendidikan dan Ilmu Geografi

27(1), 2022, 15-25

Table 5. The Result of Soil Texture Analysis

\begin{tabular}{llll}
\hline No. & Soil Texture & Area (Ha) & Percentage (\%) \\
\hline 1 & Dusty clay & 64035.67 & 55.92 \\
2 & Clay texture & 11989.18 & 10.47 \\
3 & Clay & 34863.04 & 30.45 \\
4 & No Data & 3621.15 & 3.16 \\
\hline & Total & 114509.04 & 100 \\
\hline
\end{tabular}

The last parameter used to construct a surface runoff model by curve number using remote sensing data is the soil texture. Soil texture in this research is used for curve number analysis which shows the size of runoff value that happened. The amount of runoff combined with the soil texture information contained in a region can be used as the initial identification of possible soil erosion. The data analysis results show that Banjarnegara Regency is dominated by the texture of clay soil, where the results are obtained from laboratory analysis. The texture of dusty clay soil covered the area of $55.92 \%$ or $64,035.67 \mathrm{Ha}$, then the clay texture of $34,863.04 \mathrm{Ha}$ or $30.45 \%$, and the clay of $11,989.18 \mathrm{Ha}$ or $10.47 \%$ of the total area in Banjarnegara. The result of soil texture analysis in the research area is shown in Table 5.

The curve number in this Research is a value indicating the size of runoff that occurred in the research area. Curve number values were obtained from the data of land use interpretation and soil texture analysis in the field. Data from the interpretation of land use in the laboratory is done in the field checking stage to obtain good interpretation accuracy results. In addition to getting good interpretation results, field checks were also conducted to reassemble land use classes into land use classes using SCS (Soil Conservation Service). Types of land use based on the SCS method have disadvantages and advantages, where the excess number of classes used in the classification of land use types tends to be minimal, i.e., five classes of land use. The five classes of land use include forest, grass, farmland, settlements, and fallow land, the disadvantage being the fifth classification of land use is reclassified into more detailed classes, for example, land use types are differentiated into a good forest, medium forest, and forest damaged condition. The reclassification stage is done to obtain the value of runoff to be more detailed. Grouping land use types is associated with the poor condition of the land use in certain soil groups. So, this research is done texture analysis in the field to get soil texture class. The soil texture class is divided into four groups, namely groups A, B, C, and D. Each of the soil hydrologic groups has different properties in water absorbing into the soil. The soil group A has the texture of the sand, group B is sandy clay, group C is clay, and group D is very clay. Curve number values obtained from the results of data analysis are then classified. The basic classification of curve number values refers to the cluster shown in Table 6 .

Table 6. Classification and Scoring of Curve Numbers

\begin{tabular}{llll}
\hline No. & Curve Numbers Class & Description & Score \\
\hline 1 & $76-100$ & Very High & 1 \\
2 & $51-75$ & High & 2 \\
3 & $21-50$ & Moderate & 3 \\
4 & $\leq 20$ & Low & 4 \\
\hline
\end{tabular}


Jurnal Pendidikan Geografi:

Kajian, Teori, dan Praktek dalam Bidang Pendidikan dan Ilmu Geografi

$27(1), 2022,15-25$

Table 7. Classification and Scoring of Curve Numbers

\begin{tabular}{llll}
\hline No. & Curve Numbers Class & Description & Score \\
\hline 1 & $76-100$ & Very High & 1 \\
2 & $51-75$ & High & 2 \\
3 & $21-50$ & Moderate & 3 \\
4 & $\leq 20$ & Low & 4 \\
\hline
\end{tabular}

The curve number in this Research is a value indicating the size of runoff that occurred in the research area. Curve number values were obtained from the data of land use interpretation and soil texture analysis in the field. Data from the interpretation of land use in the laboratory is done in the field checking stage to obtain good interpretation accuracy results. In addition to getting good interpretation results, field checks were also conducted to reassemble land use classes into land use classes using SCS (Soil Conservation Service). Types of land use based on the SCS method have disadvantages and advantages, where the excess number of classes used in the classification of land use types tends to be minimal, i.e., five classes of land use. The five classes of land use include forest, grass, farmland, settlements, and fallow land, the disadvantage being the fifth classification of land use is reclassified into more detailed classes, for example, land use types are differentiated into a good forest, medium forest, and forest damaged condition. The reclassification stage is done to obtain the runoff value to be more detailed. Grouping land use types is associated with the poor condition of the land use in certain soil groups. So, this research is done texture analysis in the field to get soil texture class. The soil texture class is divided into four groups, namely groups A, B, C, and D. Each of the soil hydrologic groups has different properties in water absorbing into the soil. The soil group A has the texture of the sand, group B is sandy clay, group C is clay, and group D is very clay. Curve number values obtained from the results of data analysis are then classified. The basic classification of curve number values refers to the cluster shown in Table 7.

The data analysis results show that the runoff that occurred in Banjarnegara Regency tends to be high, that is $61.24 \%$ of the total area of the research area. Distribution of runoff that occurred in high scale distributed evenly ranging from the south to north Banjarnegara District, mainly is in the form of hilly land whose land is exploited for the type of land use plantation. Large runoff with very high/extreme class spread on the form of hilly land to the old volcano complex at the study site. The runoff in the medium to low class only covers $3.56 \%$ of the total area and is distributed on the fluvial form with the flat-to-flat slopes. The result of the analysis of runoff data is obtained from slope analysis and type of land use in the research location. Increasingly steep slope with little vegetation land use, the greater the runoff that occurs. Surface runoff in Banjarnegara Regency is shown in Figure 4.

These research results could be implemented into higher student class activity, especially in remote sensing classes, GIS, cloud computing, and big data analysis. This process will add the student's skill to analyze imagery data and create new information derived from the data. The analyzing data can be composed with an appropriate spatial-temporal data set. Then, it could be adapted into another location with similar or different cases. 


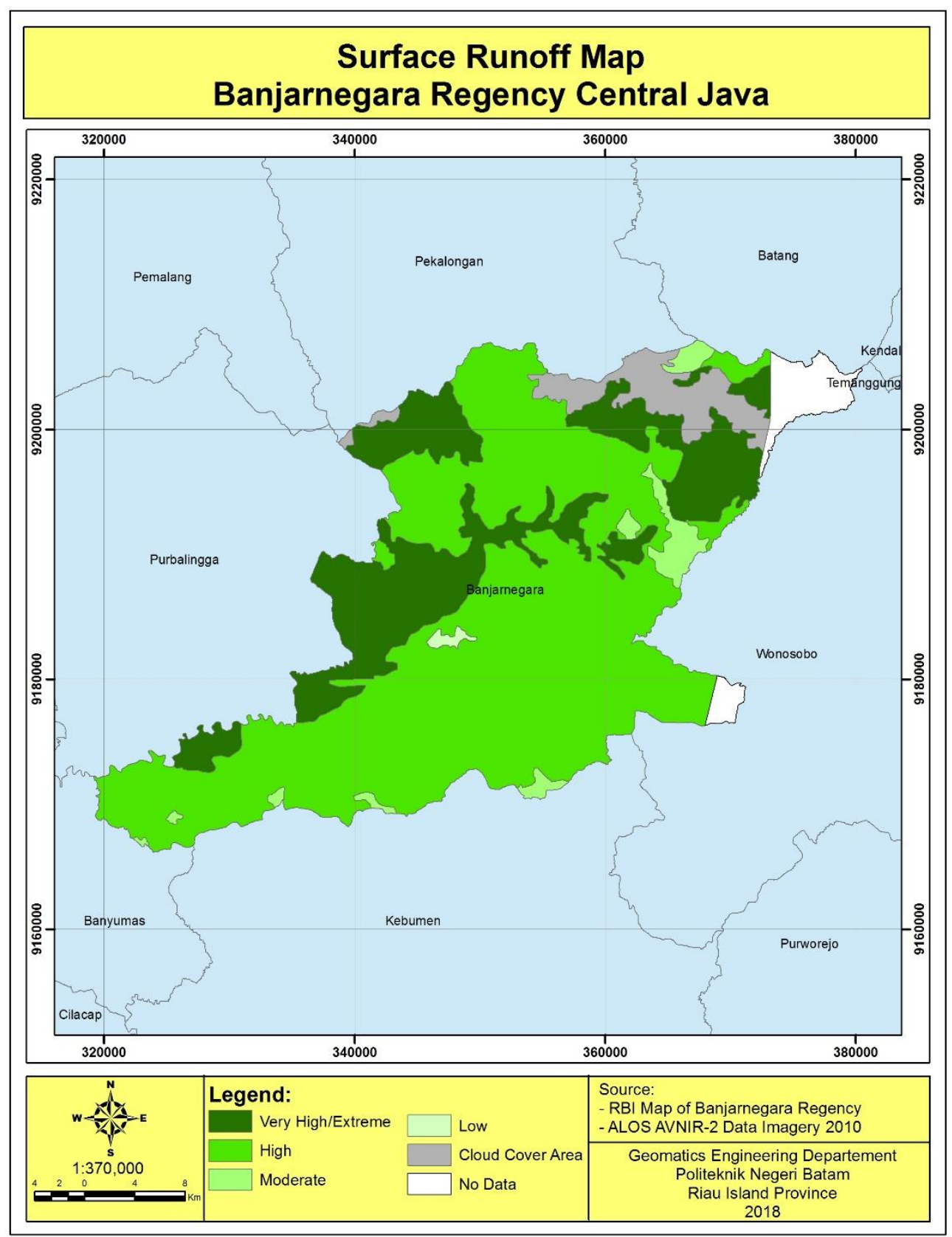

Figure 4. Surface Runoff in Banjarnegara Regency

\section{Conclusion}

The runoff that occurred in Banjarnegara Regency tends to be high, that is, $61.24 \%$ of the total area of the research area. Large runoff with very high/extreme class spread on the form of hilly land to the old volcano complex at the study site. The runoff in the medium to low class only covers $3.56 \%$ of the total area and is distributed on the fluvial form with the flat-toflat slopes. The result of the analysis of runoff data is obtained from slope analysis and type of land use in the research location. Increasingly steep slope with little vegetation-land use, the greater the runoff that occurs. Finally, the research could be implemented into higher student class activity, especially in remote sensing classes, GIS, cloud computing, and big data analysis. By this process, the student's will be improved their skill in analyzing imagery data and creating new information derived from the remote sensing data. 


\section{Jurnal Pendidikan Geografi: \\ Kajian, Teori, dan Praktek dalam Bidang Pendidikan dan Ilmu Geografi}

27(1), 2022, 15-25

\section{References}

Ahmad, I., \& Verma, M. K. (2018). Application of analytic hierarchy process in water resources planning: A GIS based approach in the identification of suitable site for water storage. Water Resources Management, 32(15), 5093-5114. https://doi.org/10.1007/S11269-018-2135-X

Anurogo, W., Lubis, M. Z., Pamungkas, D. S., Hartono, H., \& Ibrahim, F. M. (2017). A spatial approach to identify slum areas in East Wara Sub-Districts, South Sulawesi. IOP Conference Series: Earth and Environmental Science, 98(1), 1-13. https://doi.org/10.1088/1755-1315/98/1/012030

Anurogo, W,. Lubis, M. Z., \& Mufida, M. K. (2018). Modified soil-adjusted vegetation index in multispectral remote sensing data for estimating tree canopy cover density at rubber plantation. Journal of Geoscience, Engineering, Environment, and Technology, 3(1), 15. https://doi.org/10.24273/JGEET.2018.3.01.1003

Anurogo, W., Murti, S. H., \& Khakhim, N. (2015). Analisis perubahan hutan mangrove dalam penentuan kawasan rehabilitasi dan perubahan stok karbon menggunakan data Penginderaan Jauh (di Teluk Banten, Serang Provinsi Banten). Universitas Gadjah Mada.

Danoedoro, P. (2012). Pengantar Penginderaan Jauh. Penerbit Andi.

Ebrahimian, A., Gulliver, J. S., \& Wilson, B. N. (2018). Estimating effective impervious area in urban watersheds using land cover, soil character and asymptotic curve number. Hydrological Sciences Journal, 63(4), 513-526. https://doi.org/10.1080/02626667.2018.1440562

Guswa, A. J., Hamel, P., \& Meyer, K. (2017). Curve number approach to estimate monthly and annual direct runoff. Journal of Hydrologic Engineering, 23(2), 04017060. https://doi.org/10.1061/(ASCE)HE.19435584.0001606

Lal, M., Mishra, S. K., Pandey, A., Pandey, R. P., Meena, P. K., Chaudhary, A., Jha, R. K., Shreevastava, A. K., \& Kumar, Y. (2016). Evaluation of the soil conservation service curve number methodology using data from agricultural plots. Hydrogeology Journal, 25(1), 151-167. https://doi.org/10.1007/S10040-016$1460-5$

Lian, H., Yen, H., Huang, J. C., Feng, Q., Qin, L., Bashir, M. A., Wu, S., Zhu, A. X., Luo, J., Di, H., Lei, Q., \& Liu, H. (2020). CN-China: Revised runoff curve number by using rainfall-runoff events data in China. Water Research, 177, 115767. https://doi.org/10.1016/J.WATRES.2020.115767

Lubis, M. Z., Anurogo, W., Hanafi, A., Kausarian, H., Taki, H. M., \& Antoni, S. (2018). Distribution of benthic habitat using Landsat-7 Imagery in shallow waters of Sekupang, Batam Island, Indonesia. Biodiversitas Journal of Biological Diversity, 19(3), 1117-1122. https://doi.org/10.13057/BIODIV/D190346

Sari, R., Anurogo, W., \& Lubis, M. Z. (2018). Pemetaan sebaran suhu penggunaan lahan menggunakan Citra Landsat 8 di Pulau Batam. Jurnal Integrasi, 32(1), 2548-9828.

Satheeshkumar, S., Venkateswaran, S., \& Kannan, R. (2017). Rainfall-runoff estimation using SCS-CN and GIS approach in the Pappiredipatti watershed of the Vaniyar sub basin, South India. Modeling Earth Systems and Environment, 3, 24. https://doi.org/10.1007/s40808-017-0301-4

Savvidou, E., Efstratiadis, A., Koussis, A. D., Koukouvinos, A., \& Skarlatos, D. (2018). The curve number concept as a driver for delineating hydrological response units. Water, 10(2), 194. https://doi.org/10.3390/W10020194

Singhai, A., Das, S., Kadam, A. K., Shukla, J. P., Bundela, D. S., \& Kalashetty, M. (2019). GIS-based multi-criteria approach for identification of rainwater harvesting zones in upper Betwa sub-basin of Madhya Pradesh, India. Environment, Development and Sustainability, 21(2), 777-797. https://doi.org/10.1007/S10668017-0060-4/TABLES/11

Sudira, P., Purwadi, T., Sukresno, S., \& Nurlaili, M. (2017). Prediksi aliran permukaan menggunakan modifikasi model bilangan kurva. Agritech, 25(1), 10-14. https://doi.org/10.22146/AGRITECH.13372

Tiwari, K., Goyal, R., \& Sarkar, A. (2018). GIS-based methodology for identification of suitable locations for rainwater harvesting structures. Water Resources Management, 32(5), 1811-1825. https://doi.org/10.1007/S11269-018-1905-9

Uwizeyimana, D., Mureithi, S. M., Mvuyekure, S. M., Karuku, G., \& Kironchi, G. (2019). Modelling surface runoff using the soil conservation service-curve number method in a drought prone agro-ecological zone in Rwanda. International Soil and Water Conservation Research, 7(1), 9-17. https://doi.org/10.1016/J.ISWCR.2018.12.001 
Jurnal Pendidikan Geografi:

Kajian, Teori, dan Praktek dalam Bidang Pendidikan dan Ilmu Geografi

27(1), 2022, 15-25

Zeng, Z., Tang, G., Hong, Y., Zeng, C., \& Yang, Y. (2017). Development of an NRCS curve number global dataset using the latest geospatial remote sensing data for worldwide hydrologic applications. Remote Sensing Letters, 8(6), 528-536. https://doi.org/10.1080/2150704X.2017.1297544 